\title{
繰返し衝撃引張荷重に対するエポキシ樹脂注形材 の衝撃疲労強度とその信頼性 ${ }^{\dagger}$
}

\author{
岡 部 永 年* 矢 野 利 行** \\ 鎌田功***森忠夫圤*
}

\section{Impact Tensile Fatigue Strength and Reliability for Filler Reinforced Epoxy Resin Castings Subjected to Repeated Tensile Loads}

by

\author{
Nagatoshi OKabe, Toshiyuki Yano \\ (Heavy Apparatus Engineering Lab., Toshiba Co., Fuchu) \\ Isao KAMATA \\ (Hamakawasaki Works, Toshiba Co., Kawasaki) \\ and Tadao MORI \\ (Heavy Apparatus Engineering Lab., Toshiba Co., Tsurumi)
}

The impact tensile fatigue tests were conducted on alumina and silica filler reinforced epoxy resin castings. From the experiments, the properties of these resin castings under repeated impact tensile loads were clarified and the scatter properties of their strength were statistically analyzed. Safety factors and allowable stresses for resin castings under service impact tensile loading were studied on the basis of failure probability theory. The results were as follows:

(1) The fatigue tensile strength $\sigma_{t}$ of resin castings subjected to repeated impact tensile loading shows a scatter of logarithmic normal distribution and can be estimated statistically by the following formula.

$$
\sigma_{t} N_{f} m_{t}=\xi D_{t} \mu_{t} S_{t}{ }^{u}
$$

where $m_{t}$ and $D_{t}$ are the parameters of impact fatigue properties, $N_{f}$ is the life to failure, $\hat{\mu}_{t}$ and $S_{t}$ are statistical values and $u$ is the parameter of probability.

(2) The strength constant $D_{t}$ is closely related to the static tensile strength $\sigma_{B}$, and it can be estimated from the latter.

(3) The safety factor and the allowable stress of these resin castings under service impact loads can be determined according to the expectative failure probability. It is useful for the most suitable structural design.

(Received Apr. 11, 1983)

キー・ワード : 粒子分散強化形エポキシ樹脂注形材, 衝撃引張疲労強度, ばらつき特性, 安全率, 信頼性

\section{1 緒言}

粒子分散形プラスチック複合材料は，重電開閉機器 に括ける絶縁構造部材として支持碍子や碍管めるいは 絶縁操作部品に盛儿に使用されている. 従来, この種 の複合材料には機械的強度をほとんぞ期待せず，諸電

$\dagger \quad$ 本報を「絶縁構造材料の衝撃破壊強度とその信頼性 (第 3 報)」 (Impact Strength and Reliability of Insulating Structura1 Materials, III) とする.

原稿受理 昭和58年 4 月11日

* 正会員 東京芝浦電気( 株) 重電技術研究所 府中市東芝町

** 東京芝浦電気(株) 重電技術研究所 府中市東芝町

*** 東京芝浦電気(株)東芝浜川崎工場 川崎市川崎区浮島町

**** 正会 員 東京芝浦電気(株)重電技術研究所

横浜市鶴見区末広町
気的特性（耐電圧, 絶縁抵抗, 耐アーク性, 耐トラッ キング性など）が重視されてきたが，最近では機器の コンパクト化や構造合理化，あるいは大電圧大容量化 に伴い静的荷重のみならず苛酷な衝撃荷重をる絶縁構 造部材に直接担わせるような設計が行われるようにな り, 機械的強度メンバーとしての長期信頼性も要求さ れる。それゆえ，機械強度設計上，衝撃負荷に対する 疲労強度やその信頼性が非常に重要視されるようにな ってきた。

そこで, 本研究では, 前報での繊維強化形プラスチ ック複合材料としてのエポキシ樹脂積層材に引き続き， 重電開閉機器において要求される前述の諸電気的特性 
に優れるエポキシ樹脂にアルミナ粒子やシリカ粒子を 混入させた粒子分散強化形プラスチック複合材料とし てのエポキシ樹脂注形材に対して衝撃引張荷重下での 疼労強度特性についての究明，並びにその強度のばら つき特性についての解析を行った。 その結果, エポキ シ樹脂材の衝撃引張疲学強度は, エポキシ樹脂積層材 の場合同様, 各静的引張強さ並びに先のばらつきの統 計量から破壤確率論的に推定できることを明らかにし た。また，実機重電開閉機器での機械強度設計に抽い て不可欠な負荷の方のばらつきを考慮し, 開閉動作時 の実働衝撃負荷に対する絶縁構造部材の安全率（中央 安全率）あるいは許容応力（設計応力）学破壞確率論 的に決定する信頼性設計法についても検討した。

$$
2 \text { 実験 }
$$

\section{$2 \cdot 1$ 供試材および試験片}

本実験に供した粒子分散強化形複合材料としてのニ ポキン樹脂注形材（以下，単に注形材と記す）は分散 強化材として湿式あるいは乾式のアルミナ粒子，ある いはシリカ粒子をそれぞれ充てんしたエポキシ樹脂を 使用し，Fig. 1 に示すような寸法形状の試験片を金型 注形で直接作製した。この試験片の両端にはエポキシ 樹脂との接合性のよい前処理を施した雌ねじ付き金属 ブッシュが埋め达まれている。これらの注形材の基本 樹脂組成就よ゙硬化条件を Table I に示す.

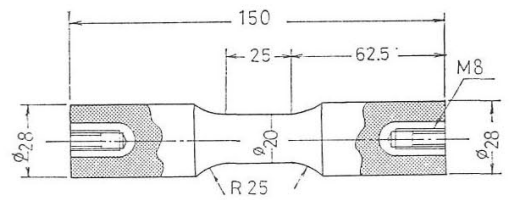

Fig. 1. Geometry of a specimen.

\section{$2 \cdot 2$ 実験方法}

衝撃疲労試験には, 円筒と丸棒との繸衝撃現象を利 用した繰返し衝撃引張荷重装置を用いた。 Fig. 2 は試 験片に対する衝撃引張負荷方式, 並びに試験片の取り

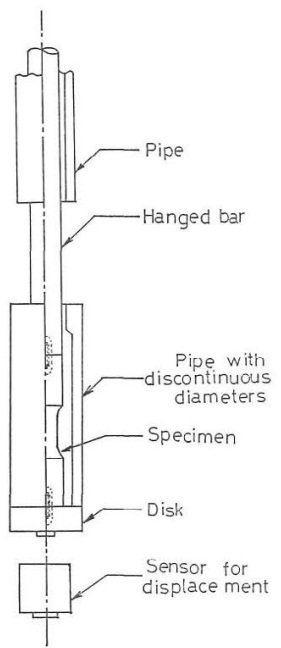

Fig. 2. Method of impact tensile loading.

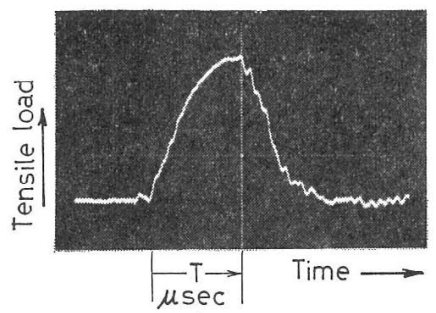

Fig. 3. Wave pattern of impact tensile loading.

付け状態を示したものである。円筒の自由落下による 1 回の衝撃によって試験片には, Fig. 3 に示すような 単一パルスの引張応力が作用する。この実測波形中に 示す $T$ は負荷上昇開始時点から除荷過程に入るまでの 時間を表しここでこの時間 $T$ を衝撃引張応力の負荷 持続時間之定義しておくと，その負荷持続時間 $T$ は円 筒の長さによって決まり，その長さが長くなるほど， 負荷持続時間Tは長くなる。

実験方法としては，大気中，室温にて任意の設定落 下高さから円筒を繰返し自由落下させ，試験片が破断

Table I. Resin composition and cure condition for various filler reinforced casting resins.

\begin{tabular}{|c|c|c|c|c|c|}
\hline & & \multicolumn{2}{|c|}{ Composition } & \multirow{2}{*}{$\begin{array}{l}\text { Weight } \\
\text { ratio }\end{array}$} & \multirow{2}{*}{ Condition of cure } \\
\hline & specimen & & ting resin & & \\
\hline \multirow{3}{*}{$\begin{array}{l}\text { Alumina filler reinforced } \\
\text { casting epoxys }\end{array}$} & $\lceil A-I\rceil$ & $\begin{array}{l}\text { Resin } \\
\text { Hardener } \\
\text { Filler }\end{array}$ & $\begin{array}{l}\text { Bisphenol epoxy } \\
\text { Acid-anhydride } \\
\text { Dry alumina }\end{array}$ & $\begin{array}{r}100 \\
30 \\
250\end{array}$ & \multirow{3}{*}{$\begin{array}{l}\text { Precure : } 115^{\circ} \mathrm{C} \times 5 \text { hours } \\
\text { Aftercure : } 130^{\circ} \mathrm{C} \times 10 \text { hours }\end{array}$} \\
\hline & \multirow{2}{*}{ [A-II] } & Resin & $\begin{array}{l}\text { Bisphenol epoxy } \\
\text { Cycloaliphatic epoxy }\end{array}$ & $\begin{array}{l}90 \\
10\end{array}$ & \\
\hline & & $\begin{array}{l}\text { Hardener } \\
\text { Filler }\end{array}$ & $\begin{array}{l}\text { Acid-anhydride } \\
\text { Wet alumina }\end{array}$ & $\begin{array}{r}30 \\
250\end{array}$ & \\
\hline $\begin{array}{l}\text { Silica filler reinforced } \\
\text { casting epoxys }\end{array}$ & [S] & $\begin{array}{l}\text { Resin } \\
\text { Hardener } \\
\text { Filler }\end{array}$ & $\begin{array}{l}\text { Bisphenol epoxy } \\
\text { Acid-anhydride } \\
\text { Silica }\end{array}$ & $\begin{array}{r}100 \\
30 \\
250\end{array}$ & $\begin{array}{l}\text { Precure : } 120^{\circ} \mathrm{C} \times 12 \text { hours } \\
\text { Aftercure : } 120^{\circ} \mathrm{C} \times 15 \text { hours }\end{array}$ \\
\hline
\end{tabular}


するまでの衝撃負荷の絽返し数を疲労破壊寿命 $N_{f}$ と した. 試験片に作用する衝撃引張荷重 $F_{t}$ の大きさは 円筒の設定落下高さ $h$ の平方根 $\sqrt{h}$ に比例し次式で表 される.

$$
\begin{gathered}
F_{t}=\alpha_{t} \sqrt{h} \\
\text { ここで, } \alpha_{t}: \text { 実験定数 }
\end{gathered}
$$

したがって, 破壊寿命 $N_{f}$ に対する衝撃引張疲労強度 としては，円筒の設定高さ $h$ 基に式(1)で算出した衝 撃引張荷重 $F_{t}$ を試験片破断部の初期断面積 $A_{0}$ で除 した公称引張応力 $\sigma_{t}$ を用いてデータの整理を行った。 な和, 衝撃引張応力の負荷持続時間 $T$ としては, 円筒 の長さ $L=1000,2000,3000 \mathrm{~mm}$ の各場合での, $T \doteqdot 400,800,1200 \mu \mathrm{sec}$ で実験を行った.

\section{3 実験結果および考察}

\section{$3 \cdot 1$ 各注形材の衝撃引張疲学強度特性}

Fig. 4 は 3 種類の各注形材 [A-I], [A-II], [S ]
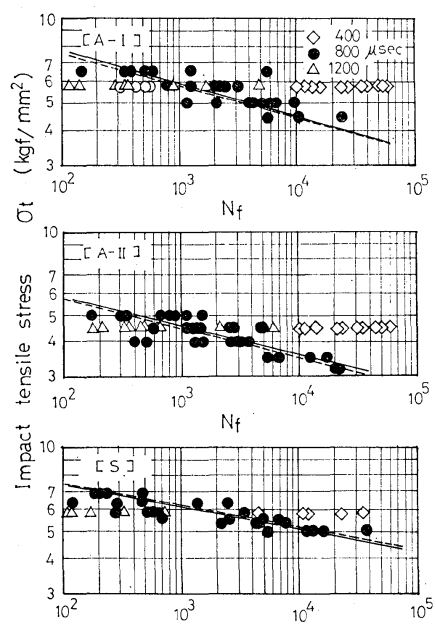

Life to failure $\mathrm{N}_{+}$

Fig. 4. Relation between the life to failure and tensile stress for various resin castings subjected to repeated impact tensile loads.

が，それどれ単一パルスの安全片振衝撃引張荷重を 繰返し受けた場合の衝撃引張応力 $\sigma_{t}$ と破壊寿命 $N_{f}$ との関係を示したものである．負荷持続時間 $T=800$

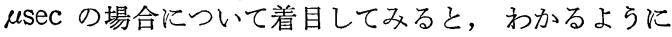
いずれの注形材に打いても衝撃負荷の繰返し数の增加 とともに疲労損傷の累積による強度低下が明りょうに 認められ， $\sigma_{t}$ と $N_{f}$ との関係は次式で表される.

$$
\sigma_{t} N_{f}^{m_{t}}=D_{t}
$$

ここで, $m_{t}, D_{t}$ : 衝撃引張疲労強度特性パラメー 及

Fig. 4 中の実線は $T=800 \mu \mathrm{sec}$ の場合の各衝撃疲労 強度データに対して最小 2 乗法により式(2)を決定した ときの推定值を示している. 一方, 衝撃引張応力 $\sigma_{t}$
の大きさを一定にしてその負荷持続時間のみを変えて $T=400,800,1200 \mu \mathrm{sec}$ とした場合の各衝撃疲労強 度データに着目してみると，破壊寿命 $N_{f}$ に明りょう な負荷持続時間依存性が認められ，負荷持続時間 $T$ が 長くなるほど破壊寿命 $N_{f}$ は短くなる傾向がある.

そこで, 疲労損傷の累積による強度低下の傾向，す なわち，強度劣化指数 $m_{t}$ は負荷持続時間 $T$ 亿無関係 に一定な材料定数であると仮定して式(2)で各負荷持続 時間 $T=400,800,1200 \mu \mathrm{sec}$ に括訂る強度定数 $D_{t}$ を求め, $D_{t}$ と $T$ との関係を両対数の関係で表すと, Fig. 5 のようになる. 両者の関係はいずれの注形材に

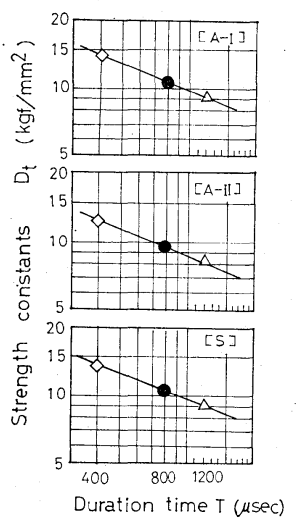

Fig. 5. Relation between duration time of impact tensile loading $T$ and strength constant $D_{t}$ for impact fatigue.

おいてもほぼ直線関係に㐫り，次式で表すことができ る.

$$
D_{t}=D_{t} * T^{-n_{t}}
$$

したがって，式(2)，(3)より繰返し衝撃引張荷重に対 する各注形材の疲労強度 $\sigma_{t}$ およびその負荷持続時間 依存性は次式で表されることになる。

$$
\sigma_{t} N_{f} m_{t} T^{n_{t}}=D_{t}^{*}
$$

ここで, $n_{t}:$ 負荷持続時間依存指数

$$
D_{t}{ }^{*}: \text { 強度定数 }
$$

Table II は全実験データを基に最小 2 乗法で決定 した衝撃引張疲労強度特性パラメータ $\left(m_{t}, n_{t}, D_{t}\right.$ *, $D_{t}$ ) を示す。なお，式(2)飞护沙強度定数 $D_{t}$ は式(4) に抢いて $T=800 \mu \mathrm{sec}$ の場合の值に相当し, 次式の

Table II. The parameters $m_{t}, n_{t}, D_{t}^{*}, D_{t}$ of impact tensile fatigue strength properties.

\begin{tabular}{c|c|c|c|c}
\hline \multirow{2}{*}{ Specimen } & \multicolumn{2}{|c|}{ Dependent exponents } & \multicolumn{2}{|c}{ Strength constants } \\
\cline { 2 - 5 } \cline { 5 - 5 } & $m_{t}$ & $n_{t}$ & $D_{t}^{*}$ & $D_{t}$ \\
\hline \multirow{2}{*}{$\mathrm{A}-\mathrm{I}$} & 0.1195 & 0.3943 & 0.6395 & 10.64 \\
{$[\mathrm{~A}-\mathrm{II}\rceil$} & 0.1061 & 0.4012 & 0.5464 & 9.550 \\
{$[\mathrm{~S}]$} & 0.07943 & 0.3845 & 0.6838 & 10.61 \\
\hline
\end{tabular}


ように表したときの強度定数 $D_{t}$ である.

$$
\sigma_{t} N_{f} m_{t}=(0.0008 / T)^{n} D_{t}
$$

したがって， $(0.0008 / T)^{n_{t}} \equiv \xi$ なる負荷持続時間依 存係数乡を定義することにより, 繰返し衝撃引張荷重 に対する疲労強度は，一般に次式で表されることにな る.

$$
\sigma_{t} N_{f}^{m_{t}}=\xi D_{t}
$$

ついで, Fig.4，5 にみられる以上のような衝撃引張 疲学強度特性について, それぞれ, 各注形材の間で比 較しながら考察をする。

同種のアルミナ粒子分散強化形の注形材 [A-I ] , 〔A-II〕に执いて強度レベル差があり, 注形材〔AI 〕の方が注形材 [A-II]より明らかに高強度レベル を示すのはエポキシ樹脂の強度特性の差に起因すると ころが大きいすなおち，注形材 [A-I]の方は延性 を有し常温破壊強度に優れるビスフェノール系のみの

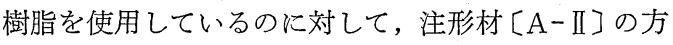
は熱変形強度には優れるがぜい性を有し常温破壊強度 飞劣るシクロアリファティック系の樹脂を混合して使 用しているので, それによる常温破壞強度の差の現れ であると考兄る. 一方, 同一のビスフェノール系エ ポキシ樹脂のみを使用しているアルミナ粒子分散強化 形の注形材 [A-I $]$ とシリカ粒子分散強化形の注形材 [S]とに和いても強度レベル差があり, 注形材 [S] の方が注形材 [A-I]ょり高強度レベルにあり，しか も，その強度レベル差は高寿命側になるほど大きくな る傾向がある。これは粒子とエポキシ樹脂との界面に 打ける接着性に起因すると考光る。すなわち，エポキ シ樹脂との接着性に優れるシリカ粒子を分散強化材と した注形材〔S】の方が高強度レベルを示していると 考える:

疲労損傷の累積による強度低下の傾きに関しては, アルミナ粒子分散強化形の両注形材 [A-I]と[AII]は汪とんぞ類似しているが, これらの注形材 [AI]，〔A-II]とシリカ粒子分散強化形の注形材 [S] とには明りょうな差があり, 注形材〔S $〕$ の方が注形 材 [A-I]，[A-II]に比べて明らかに小さいようで ある.これは, 前述の粒子とエポキシ樹脂との接着性 の差に起因した界面強度の差にあると考光る。すなわ ち, 疲労損傷の累積による強度低下は，分散するこれ らの界面強度の低下の集積であると考劣る。したがっ て, 界面強度に優的るシリカ粒子分散強化形の注形材 [S]の方が小さい強度劣化指数 $m_{f}$ を示すので市万 らと考光る。この特性の現れが，前述の注形材 [S] と注形材 [A-I]との強度レベル差の高寿命側での 増大となっている.

負荷持続時間依存性関しては，3種類の注形材に おいてほとんど差はないようである。しかしながら，
これらの注形材の $n_{t}$ は軟鋼や純銅など゙の衝撃引張疲 労に和ける負荷持続時間依存性指数 $m$ 飞比べて $4 \sim 5$ 倍の值を示すよらである.これは負荷過程での注形材 の変形が粘弾性挙動を呈するため負荷持続時間の効果 が大きいのであるらと考方る、な拈，前報での䋐維強 化形プラスチック複合材料としてのエポキシ樹脂積層 材の衝撃引張疲労では負荷持続時間の影響が $400 \mu \mathrm{S} \leqq$ $T \leqq 1200 \mu \mathrm{s}$ の範囲内で無視できた.この注形材と積 層材に括沙負荷持続時間依存性の差はエポキシ樹脂 基地中の強化材が衝撃引張荷重方向に対して断続的で あるか，連続的であるかによってエポキシ樹脂の粘弾 性特性の出現度が極度に異なったためであるう。

\section{$3 \cdot 2$ 各注形材の静的引張特性と衝撃引張疲労強度 との関係について}

Fig. 6 は各注形材の静的引張強さ $\sigma_{B}$ と式(6)におけ る強度定数 $D_{t}$ との関係を両対数の関係で示したもの

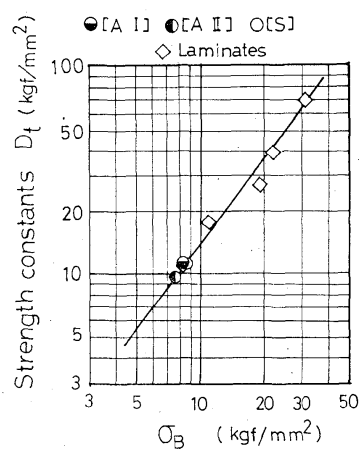

Fig. 6. Relation between static tensile strength $\sigma_{B}$ and strength constant $D_{t}$.

である. 前述のように常温での静的引張強さ $\sigma_{B}$ の強 い注形材ほど，それらの衝撃引張疲労強度レベルを決 定する強度定数 $D_{t}$ は大きな值を示すことがわかる. この両者の関係は次式で表すことができる.

$$
D_{t}=a \sigma_{B}^{b}
$$

前報での各積層材の場合も， $\sigma_{B}$ と $D_{t}$ との間には， 式(7)の関係があり, Fig. 6 中の直線は气の関係を近似 したものである、これからわかるように，各注形材に 括讨る $\sigma_{B}$ 之 $D_{t}$ との関係も, 各積層材の場合に含め て式(7)で表せる一つの直線で近似できるようである。

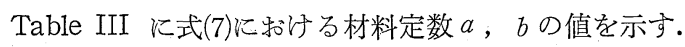

Fig. 7.は, 衝撃疲労損傷の累積による強度低下の傾 きを表す強度劣化指数 $m_{t}$ を，前報での積層材の場合

Table III. Experimental constants $a, b$ in formula (7).

\begin{tabular}{c|c}
$a$ & $b$ \\
\hline 0.6274 & 1.346 \\
\hline
\end{tabular}




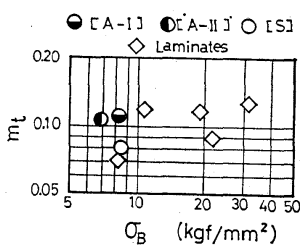

Fig. 7. Relation between static tensile strength $\sigma_{B}$ and dependent exponent $m_{t}$.

も含めて各静的引張強さ $\sigma_{B}$ との関係で示したもので ある.これからわかるよらに $m_{t}$ は $\sigma_{B}$ の大きさに依 存せず, むしろ, 前述のように強化材とエポキシ樹脂 との界面での接着性に優れるものが, 小さな $m_{t}$ の值 を示すよらである.

そこで, 強度定数 $D_{t}$ としては各注形材の静的引張 強さ $\sigma_{B}$ を基に式(7)で求め, $m_{t}$ としては注形材 $〔 \mathrm{~A}-$

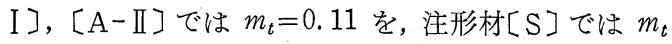
$=0.079$ を，それぞれ用い，また， $n_{t}$ としては $n_{t}=$ 0.39 を用いることにすると, 各注形材の 衝撃引張疲 労強度に対する式(5)の推定值は Fig. 4 中の各破線の ようになり, 各静的引張強さ $\sigma_{B}$ からも比較的よく推 定できることがわかる.

\section{$3 \cdot 3$ 各注形材の衝撃引張疲労強度のばらつき特性}

Fig. 8 は各注形材の衝撃引張疲労強度のばらつき分 布特性を，それぞれ示したものである. 横軸は式(5)に 基づく衝撃引張疲労強度の推定值に対する実験值の比 を次式のように $\mu_{t}$ と拈き, 対数目盛で表している.

$$
\frac{\sigma_{t} N_{f} m_{t}}{\xi D_{t}}=\mu_{t}
$$

一方, 縱軸は各 $\mu_{t}$ に対応する破壊確率 $P$ を正規確 率目盛で表している. この破壊確率 $P$ としては, 各 $\mu_{t}$ の值に対して小さい值の方から順位付けし, その順位 数 $i$ を基に次式で求めた $P$ の值を, それぞれ対応付け ている.

$$
P=\frac{i-0.5}{k}
$$

ここで, $k:$ サンプルサイズ

いずれの注形材においても, 各衝撃引張疲労強度の ばらつきは対数正規分布で近似できるようである.

そこで, 各衝撃引張疲労強度のばらつきに対して対 数正規分布を仮定し， $\mu_{t}$ の值のばらつき特性パラメ 一タ $\left(\hat{\mu}_{t}, s_{t}\right)$ を次式によって統計量として求めると, Table IV のような值を得る.

Table IV. Statistical values for impact tensile fatigue strength.

\begin{tabular}{c|c|c}
\hline Specimen & $\hat{\mu}_{t}$ & $S_{t}$ \\
\hline$\lceil\mathrm{A}-\mathrm{I}\rceil$ & 0.9997 & 1.110 \\
$\lceil\mathrm{~A}-\mathrm{II}\rceil$ & 0.9980 & 1.132 \\
$\lceil\mathrm{~S} 〕$ & 0.9897 & 1.109 \\
\hline
\end{tabular}

$$
\begin{gathered}
\hat{\mu}_{t}=\exp \frac{1}{k} \sum \ln \mu \\
S_{t}=\exp \sqrt{\frac{1}{k-1} \sum\left(\ln \mu_{t}-\ln \hat{\mu}_{t}\right)^{2}}
\end{gathered}
$$

ここで, $\left(\ln \mu_{t}-\ln \hat{\mu}_{t}\right) / \ln s_{t}=u$ とおくことにより, 各注形材の衝撃引張疲労強度 $\sigma_{t}$ は次式のようなばら つきを考慮した確率量として表すことができる.

$$
\sigma_{t} N_{f} m_{t}=\xi D_{t} \hat{\mu}_{t} s_{t}{ }^{u}
$$

$u$ は確率パラメータであり, 次式のような累積分布 関数 $\Phi(u)$ の逆関数 $\Phi^{-1}(P)$ として表される.

$$
\begin{aligned}
P(u) & =\Phi(u) \\
& =\frac{1}{\sqrt{2 \pi} \ln s} \int_{+0}^{\mu} \exp \left\{-\frac{1}{2}\left(\frac{\ln \mu-\ln \hat{\mu}}{\ln s}\right)^{2}\right\} d(\ln \mu) \\
& =\frac{1}{\sqrt{2 \pi}} \int_{-\infty}^{u} \exp \left(-\frac{u^{2}}{2}\right) d u
\end{aligned}
$$

したがって，式(12)，(13)は Fig.9 に示すように各注形 材の衝撃引張疲労に打ける $P-S-N$ 線図の推定並びに 任意破壊寿命 $N_{f}$ での疲労強度分布や任意衝撃引張負 荷条件下での破壊寿命分布の予測に適用できる.

一方, 各注形材の静的引張強さ $\sigma_{B}$ のばらつき特性
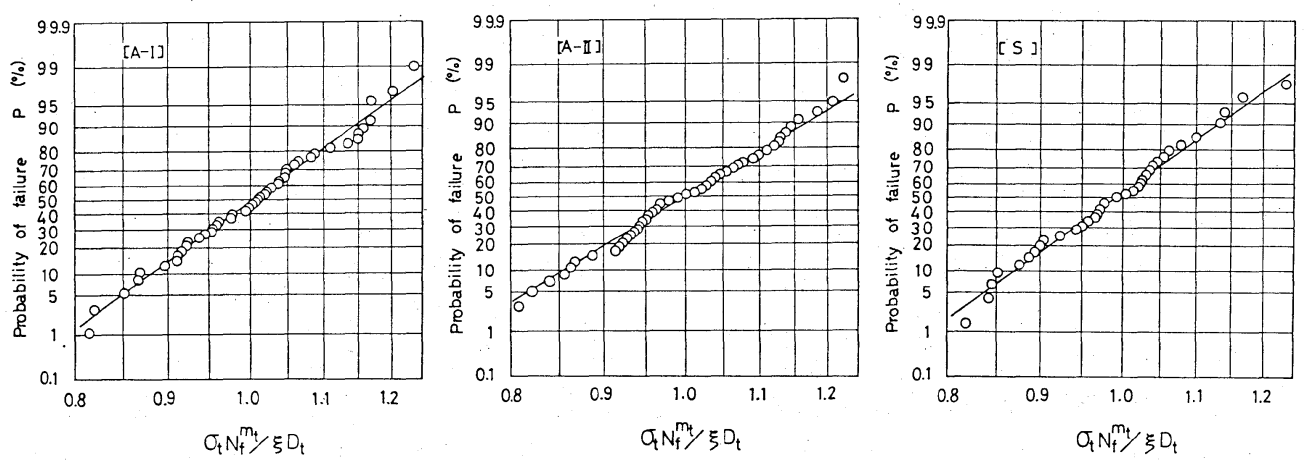

Fig. 8. Statistical distribution of impact tensile fatigue strength for various resin castings. 


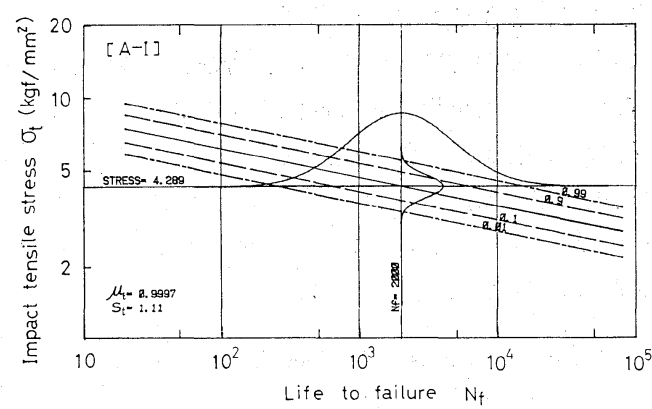

Fig. 9. The estimated $P-S-N$ diagram and the predicted distribution of failure-life and residual strength in case of [A-I].

パラメータの統計量 $\left(\hat{\sigma}_{B}, s_{\sigma_{B}}\right)$ を, 対数正規分布の 仮定のもとに求め, $s_{\sigma_{B}}$ と衝撃引張疲労強度の $s_{t}$ とを 比較してみると, いずれの注形材の場合も衝撃引張疲 労強度の方が静的引張強さ $\sigma_{B}$ より大きく，1.048〜 1.061 倍の大きなばらつきを呈す.なお, 前報での積 層材の場合と比べて $s_{t} / s_{\sigma_{B}}$ の比は幾分大きい.

各注形材の静的引張強さ $\sigma_{B}$ のばらつき特性パラメ 一夕の統計量 $\left(\hat{\sigma}_{B}, s_{\sigma_{B}}\right)$ を基に衝撃引張疲学強度の 破壊確率論的推定ができるが，その際，式(12)の $s_{t}$ に $1.06 s_{\sigma_{B}}$ の值を考慮しておく必要がある.

\section{$3 \cdot 4$ 実働衝撃荷重に対する安全率および許容応力 について}

実機での実働衝撃荷重に対する各注形部材の衝撃疲 労強度を, 機械強度設計上, 考学て行く場合, 前述の 材料強度の方のばらつきだけでなく，実機に怙いて回 避できない負荷の方のばらつきも考慮して中央安全率 （以下，単に安全率と記す）和よび許容応力を決定す ベきである.

いま, 実働衝撃荷重下で部材内に生じる応力を $\sigma_{s}$, その統計量を $\left(\hat{\sigma}_{s}, s_{s}\right)$ とし, この応力 $\sigma_{s}$ を $N_{f}$ 回 繰返し受けた場合のその部材の残留強度を $\sigma_{R}$, その 統計量を $\left(\hat{\sigma}_{R}, s_{R}\right)$ とすると, $N_{f}$ 回目の衝撃負荷で 破壊する確率は $P\left[\sigma_{R}<\sigma_{s} \mid N_{f}\right]$ であり, 次式で与兄ら れる.

$$
\begin{aligned}
P\left[\sigma_{R}<\sigma_{s} \mid N_{f}\right] & =\frac{1}{\sqrt{2 \pi}} \int_{-\infty}^{u *} \exp \left(-\frac{u^{2}}{2}\right) d u \\
u^{*} & =\frac{\ln \hat{\mu}_{s}-\ln \hat{\mu}_{R}}{\sqrt{\left(\ln s_{R}\right)^{2}+\left(V_{s} \ln \hat{\mu}_{s}\right)^{2}}}
\end{aligned}
$$

ここで， $\hat{\mu}_{s}, \hat{\mu}_{R}, V_{s}$ は，それぞれ，次式で与えら れる $\sigma_{s}, \sigma_{R}$ の統計量である.

$$
\begin{aligned}
& \hat{\mu}_{s}=\hat{\sigma}_{s} /\left(D_{t} / N_{f} m_{t}\right) \xi \\
& \hat{\mu}_{R}=\hat{\sigma}_{R} /\left(D_{t} / N_{f}^{m_{t}}\right) \xi \\
& V_{s}=\left|\ln s_{s} / \ln \hat{\mu}_{s}\right|
\end{aligned}
$$

それゆえ，任意の破壊寿命 $N_{f}$ 下で， $\left(\sigma_{R}<\sigma_{s}\right)$ とP との関係を, 式(14)から求めることにより, 安全率 $\eta=$ $\hat{\sigma}_{R} / \hat{\sigma}_{s}$ あるいは許容応力 $\hat{\sigma}_{A}$ を破壇確率論的に決定で
きることになる，なお，積分方程式(14)の $\hat{\mu}_{s}$ について の解は次式のよらになり， $\left(V_{s}, \hat{\mu}_{R}, s_{R}, u^{*}\right)$ の関数 として表される.

$$
\begin{aligned}
& \hat{\mu}_{s}= \\
& \exp \left[\frac{\ln \hat{\mu}_{R}+u^{*} \sqrt{\left\{1-\left(u^{*} V_{s}\right)^{2}\right\}\left(\ln s_{R}\right)^{2}+\left(V_{s} \ln \hat{\mu}_{R}\right)^{2}}}{1-\left(u^{*} V_{s}\right)^{2}}\right]
\end{aligned}
$$

したがって，( $\left.\hat{\mu}_{R}, s_{R}\right)$ のばらつき特性を有する注 形部材の衝撃引張応力に対する許容応力 $\sigma_{t A}$ および安 全率 $\eta$ は次式で求められる.

$$
\begin{gathered}
\sigma_{t A}=\xi\left(D_{t} / N_{f} m_{t}\right) \hat{\mu}_{s}\left(V_{s}, u^{*}\right) \\
\eta=\hat{\mu}_{R} / \hat{\mu}_{s}\left(V_{s}, u^{*}\right)
\end{gathered}
$$

そこで，以上のよらなアプローチに基づき，注形材 [A-I]を, 衝撃引張荷重が繰返し作用する絶縁構造 部材として使用寸る場合での安全率 $\eta$ の破壊確率論的 決定のための $P-\eta$ 線図を，一例として求めてみると， Fig.10のようになる. 各 $P-\eta$ 線図は, 衝撃負荷のば らつきを変動係数 $V_{s}$ で表し，この $V_{s}$ をパラメータ として，0.05，0.1，‥ 0.4と変動させた各場合の結

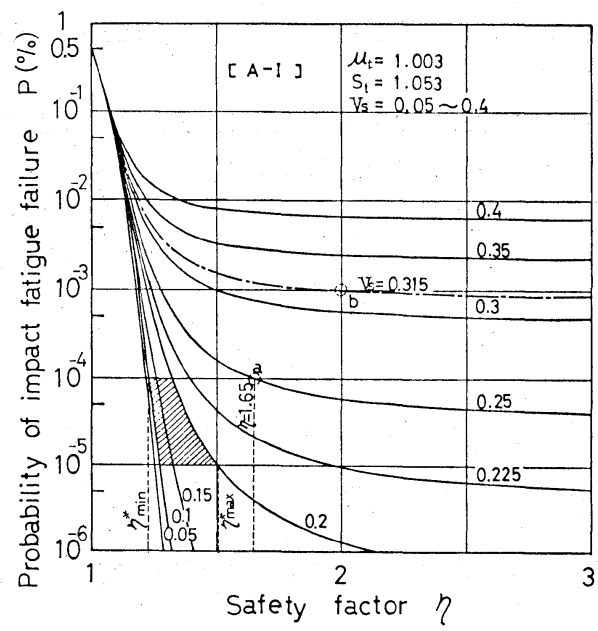

Fig. 10. Relation between probability of impact fatigue failure and safety factor under various values of variation coefficient.

果を示している.この線図の適用例としては，いま， 例えば，同図中のa点に着目してみると，“最大 $V_{s}=$ 0.25のばらつきまでの衝撃負荷に対して許容でき，乙 かも破壊確率を $P<10^{-4}$ に抑えるには, 安全率と乙 ては $\eta>1.65$ にする必要があることを知り得る。ま た，斜線部に示すように絶縁構造物の安全性と経済性 の均衡の観点から期待信頼度範囲（換言すれば，期待 破壊確率範囲: $\left.10^{-4}<P>10^{-5}\right)$ が決まり, しか子衝撃 負荷のばらつきを $0.1<V_{s}<0.2$ の範囲に抑制できる としたら，安全率を $\eta_{\min } *<\eta<\eta_{\max } *$ の範囲内に設 定し，電気絶縁特性をも勘案した強度設計を行えば， 
必要以上の安全率をとるというような不経済な設計を 回避できる、また，例えば，破壊確率を $P<10^{-3}$ に 抑えることにして安全率を $\eta=2$ に設定しようとする 設計の絶縁構造部材では, 衝撃負荷に対する最大許容 ばらつきは $V_{s \max }=0.315$ となることがわかる.この ようにPとクとを設定した条件での $V_{s \max }$ は，その 絶縁構造部に使用しよらとする注形材の種類によって 異なってくる. この $V_{s \max }$ の大きい注形材ほど, 期 待信頼度を確保できる確率が高くなる. したがって， この $V_{s \max }$ の值に着目すると, 繰返し衝撃引張荷重 を受ける絶縁構造部材として数種の注形材のらちから 適当に選定しょらとする際の評価尺度となり得ること がわかる、なお， $V_{s \max }$ を、゙らつき特性パラメータ としての $S_{s \max }$ の值で表すには, 次式を用いればよ w.

$$
S_{s \max }=\hat{\mu}_{s}^{-V_{s \max }}=\left(\hat{\mu}_{R} / \eta\right)^{-V_{s \max }}
$$

以上のような適用例からわかるように, 本研究で究 明された衝撃疲労強度特性およびそれらのデータの統 計量に基づく前述の破壊確率論的アプローチは各種重 電開閉機器のエポキシ樹脂注形絶縁構造部材に対する 機械強度上の信頼性設計あるいは信頼度評価に非常に 有益な手法となる.

\section{4 結事}

各種エポキシ樹脂注形材に対して繰返し衝撃引張荷 重による疲労強度特性の究明, 並びにそれらの強度の ばらつき特性の解析を行った。ついで, 実機において 不可欠なところのばらつきを勘案した繰返し衝撃引張 荷重に対するエポキシ樹脂注形絶縁構造部材の許容応 力あるいは安全率の決定などについて信頼性解析を行 った. 得られた結果は下記のように要約できる.

（1）繰返し衝撃引張荷重に対寸る疲労強度 $\sigma_{t}$ はい ずれの注形材も, 対数正規分布のばらつきを有し次式 によって破壊確率論的に推定できる.

$$
\sigma_{t} N_{f} m_{t}=\xi D_{t} \hat{\mu}_{t} s_{t}{ }^{u}
$$

ここで, $\left(m_{t}, D_{t}\right):$ 衝撃疲労強度特性パラメータ, $\xi$ : 負荷持続時間依存係数，( $\left.\hat{\mu}, s_{t}\right)$ : ばらつき特性パ ラメータの統計量.

（2）上式に和ける強度定数 $D_{t}$ に関しては, 各注形 材はもちろんのこと, 前報での積層材の場合も含めて 各静的引張強さ $\sigma_{B}$ と次式のような関係があり, 推定 できる。

$$
D_{t}=a \sigma_{B}^{b}
$$

また，ばらつきパラメータ $S_{t}$ に関しては， $\sigma_{B}$ のば らつきパラメータ $S_{\sigma_{B}}$ の1.06倍の值を見込めばよい.

(3) 強度劣化指数 $m_{t}$ に関しては, 静的引張強さ $\sigma_{B}$ との相関性は認められないが，充てん材がアルミナ粒 子であるか, シリカ粒子であるかによって有意差があ る.

（4）繰返乙衝撃引張荷重が作用する注形絶縁構造物 へのエポキシ樹脂注形材の適用の場合の許容応力や安 全率の破壊確率論的決定法, 安全性と経済性との均衡 を考慮した経済的設計，並びに信頼性を考慮した材料 選定への $V_{s \max }$ の適用について明らかにできた。 （昭和55年1月29日 第21回信頼性工学部門委員会にて講演）

\section{参 考 文 献}

1) 岡部永年, 矢野利行, 鎌田 功, 森 忠夫, 材料, 31 , 1210 (1982).

2) 茶谷明義, 中沢 一, 中原一郎, 日本機械学会誌, 73 , 1508 (1970).

3）岡部永年, 矢野利行, 森 忠夫, 材料, 30, 28 (1981).

4) 岡部永年, 矢野利行, 森 忠夫, 日本材料学会第 26 期学 術講演会前刷, p.179 (1977).

5) 岡部永年, 矢野利行, 森 忠夫, 第17回材料研究連合講 演会前刷集, p.141 (1974).

6) 岡部永年, 矢野利行, 森 忠夫, 第25回材料研究連合会 講演会前刷集, p.135 (1981).

7) 岡部永年, 矢野利行, 鎌田 功, 森 忠夫, 第12回日科 技連信頼性保全性シンポジウム, p.99 (1982).

8) 下河利行, 航空技研報告, TR 464 (1976). 